\title{
HERBAL TWINNING SYSTEM (HERBAL TREATMENT WITH MONITORING ANALYSIS SYSTEM): RANCANG BANGUN APLIKASI KONSELING PENYAKIT DEGENERATIF DALAM KAIDAH IPE BERBASIS ANDROID
}

\author{
Diana Gusti Ambarwati ${ }^{1)}$, Wahyu Nur Hidayati ${ }^{2)}$, Khairunnisa Aisyanti ${ }^{3)}$, Heru Supriyono ${ }^{4)}$ \\ 1,4) Program Studi Teknik Informatika, Fakultas Komunikasi dan Teknik Informatika, Universitas \\ Muhammadiyah Surakarta \\ ${ }^{2,3)}$ Program Studi Farmasi, Fakultas Farmasi, Universitas Muhammadiyah Surakarta \\ 1) dianagusti76@gmail.com, ${ }^{2)}$ wahyunurhidayati21@gmail.com, ${ }^{3)}$ khairunnisa.aisyanti@gmail.com, \\ ${ }^{4)}$ Heru.Supriyono@ums.ac.id
}

\begin{abstract}
The cause of the world's largest death is non-communicable disease or degenerative disease. According to WHO (2013) 63\% kills 36 million people per year, $80 \%$ of these deaths occur in middle and low income countries. From the economic point of view, the danger of this disease is very burdensome to the community because it requires high cost for hospitalization. Herbal Twinning System (Herbal Treatment with Monitoring Analysis System) is an android-based renewable application that is used to facilitate the sufferers of degenerative diseases to get an information about the proper and rational treatment. Health professions in the form of doctors, pharmacists, nurses, and nutritionists act as facilitators to facilitate patients in consultation related to the illness. This application has five main menu that is to health, to consultation, to herbal, to nutrition, and to discussion which contains information related to processing of simple herbal medicine that can be used as a substitute for chemical drugs, tips on healthy lifestyle, and control of patient nutrition. Application design created using android studio, XAMPP SQL, and. Notepad. The results of the application include the design of systems that can be applied in mobile phones or tablets.
\end{abstract}

Keyword: Degenerative Disease, Herbal Medicine, Interprofessional Education, Android, Herbal Twinning System

\section{PENDAhUluan}

Penyebab kematian di dunia terbesar adalah penyakit tidak menular atau penyakit degeneratif. Menurut (Breu, Guggenbichler, \& Wollmann, 2013) sebanyak 63\% yang membunuh 36 juta jiwa per tahun, $80 \%$ kematian ini terjadi di negara yang mempunyai penghasilan menengah dan rendah. Dari segi ekonomi, bahaya penyakit ini sangat membebankan masyarakat karena membutuhkan biaya mahal untuk rawat inap.

Medication Error (ME) menurut NCC MERP merupakan serangkaian proses yang dapat dihindari dan berakibat membahayakan nyawa pasien meskipun obat berada dalam pengawasan tenaga kesehatan. Berdasarkan Laporan dari Peta Nasional Insiden Keselamatan Pasien (Kongres PERSI Sep 2012) "Ketidaksesuaian dalam pemberian obat merupakan peringkat pertama (24.8\%) dari 10 besar insiden yang pernah ada. Apabila kita kaji mendalam, dalam serangkaian proses penggunaan obat yang meliputi prescribing, transcribing, dispensing dan administering, yang menduduki peringkat pertama adalah dispensing atau pada tahap pemberian”. Selain itu, terjadi perbedaan paradigma antar berbagai profesi kesehatan sehingga menyebabkan pengobatan tersebut tidak optimal dan tidak mencapai efek terapi yang diinginkan. Hal ini penting untuk merubah paradigma pelayanan kesehatan supaya terfokus pada keselamatan individu dari pasien (patient oriented). 
Indonesia termasuk negara yang memiliki lahan subur untuk ditumbuhi berbagai macam tanaman herbal karena didukung keanekaragaman hayati yang luas. Menurut (Meinarwati, 2015) bahwa kekayaan hayati di Indonesia sangat melimpah. Flora dengan jumlah 40.000 jenis yang tumbuh di dunia, sebanyak 30.000 diantaranya tumbuh di Indonesia. Sebanyak 26\% dari kekayaan alam tersebut yang dibudidayakan dan $74 \%$ masih tumbuh liar di hutan. Oleh karena itu, perlu dioptimalkan potensi obat herbal yang ada di Indonesia. Hal ini juga berfungsi untuk meminimalisir efek samping dari obat-obatan kimia bila dikonsumsi jangka panjang.

Herbal Treatment with Monitoring Analysis System (Herbal Twinning System) adalah sebuah aplikasi terbarukan berbasis android yang digunakan untuk memudahkan para penderita penyakit degeneratif untuk mendapatkan sebuah informasi mengenai cara pengobatan yang tepat dan rasional. Aplikasi ini juga dirancang untuk memudahkan penderita sehingga dapat berkomunikasi dan berbagi pengalaman dengan penderita penyakit sejenis, berkonsultasi dengan tenaga medis yang ahli dalam masing-masing bidangnya. Satu pasien ditangani oleh beberapa profesi kesehatan dari berbagai macam konsentrasi ilmu sebagai perwujudan "patient oriented" atau pengobatan yang mengorientasikan pada kesembuhan pasien.

\section{TINJAUAN PUSTAKA}

Penelitian terdahulu yang telah dilakukan oleh (Head, Arms, Watanabe, Kawakami, \& Tachi, 2009) yaitu aplikasi makanan sehat bagi penderita diabetes. Dalam penelitian ini, pasien dapat memperoleh informasi makanan sehat bagi pasien dengan cara memasukkan berat badan, umur, jenis kelamin, jenis aktivitas, dan jenis makanan. Sistem ini dapat memonitor perkembangan pasien jika pasien mempunyai data konsultasi. Aplikasi konseling yang sedang marak berkembang lainnya adalah Alodokter, haiDokter, Pasienia, DokterSehat, Lokadok, dsb. Aplikasi tersebut memiliki keunggulan antara lain adalah selalu ada dokter yang menjawab, majalah kesehatan, database penyakit dan obatnya.

Perbedaan aplikasi yang pernah ada dengan Herbal Twinning System yang kami usung adalah pada ruang lingkup konseling dan pengobatan. Dalam konsep kami, konseling dilakukan oleh beberapa profesi kesehatan yang meliputi dokter, apoteker, perawat, dan ahli gizi sehingga perbedaan presepsi antar tenaga kesehatan dapat diminimalisir. Mereka berpadu untuk menangani satu pasien saja, sehingga terciptalah pengobatan rasional yang berorientasi pada pasien. Perbedaan lainnya adalah pada terapi pengobatan. Konsep kami menjunjung tinggi pengobatan herbal untuk segala macam penyakit degeneratif sebagai langkah pencegahan dari efek samping obat kimia yang tidak di inginkan apabila dikonsumsi jangka panjang.

\section{Adapun}

\subsection{Penyakit Degeneratif}

Pertambahan umur seseorang akan menyebabkan penurunan fungsi biologis yang akan menyababkan menurunnya daya tahan tubuh sehingga penyakit tidak menular akan dialami pada usia lanjut. Penyakit tidak menular pada lansia di antaranya hipertensi, stroke, diabetes mellitus dan radang sendi atau rematik. (Kemenkes RI, 2012)

\subsection{Potensi Tanaman Herbal}

Sejak 2008, industri obat Indonesia berbasis jamu mulai berkembang. Indonesia memiliki 30.000 jenis tumbuhan dan 7.000 diperkirakan memiliki khasiat obat. Terdapat 2.500 memiliki khasiat sebagai obat (Mendag, 2014). Pada tahun 2013, nilai 
ekspor obat herbal Indonesia mencapai US\$ 23,44 juta. Tahun 2009-2013 pertumbuhan ekspor obat herbal Indonesia mengalami kenaikan 6,49\% per tahun. Dengan data tersebut, menunjukkan bahwa tanaman herbal Indonesia memiliki potensi sebagai pengganti pengobatan bagi masyarakat.

\subsubsection{Interprofesional Education (IPE)}

Interprofesional Education (IPE) merupakan pembelajaran yang diikuti oleh dua atau lebih bidang profesi kesehatan yang berbeda dengan meningkatkan kolaborasi. Kolaborasi dua atau lebih bidang profesi bertujuan untuk meningkatkan pelayanan dan pelaksanaan klinik. Dengan adanya kolaborasi dari berbagai bidang, diharapkan pelayanan kesehatan berorientasi kepada pasien. Selama ini pelayanan kesehatan menganggap pasien sebagai objek, bukan sebagai subjek. Kolaborasi antar profesi kesehatan adalah satu usaha untuk peningkatan mutu pelayanan kesehatan (Hind, 2003).

\subsubsection{JavaScript}

JavaScript merupakan bahasa script yang ditempelkan di kode html juga diproses di sisi klien. Bahasa ini memungkinkan pada kemampuan merubah menjadi semakin luas dokumen HTML. JavaScript memungkinkan untuk memvalidasi data input pada formulir sebelum formulir tersebut dikirimkan ke server. JavaScript bukan merupakan bahasa Java atau merupakan hal yang sangat berbeda. JavaScript diinterpretasikan klien, sedangkan kode Java dikompilasi seorang pemrogram sehingga hasil dari kompilasinya dapat dijalankan oleh klien.

\subsubsection{XAMPP}

XAMPP adalah sebuah aplikasi yang berisi Apache, MariaDB (pengganti MySQL), PHP, dan Perl. XAMPP merupakan sebuah paket open source yang dirancang supaya mudah untuk digunakan. Selain itu XAMPP termasuk crossplatform sehingga bisa berjalan baik di Windows, Linux, atau Mac-OS.

\section{METODE PENELITIAN}

Dalam pengembagan aplikasi, metode yang digunakan adalah System Development Life Cycle (SDLC) menggunakan waterfall approach yang alurnya dapat dilihat pada Gambar 1.

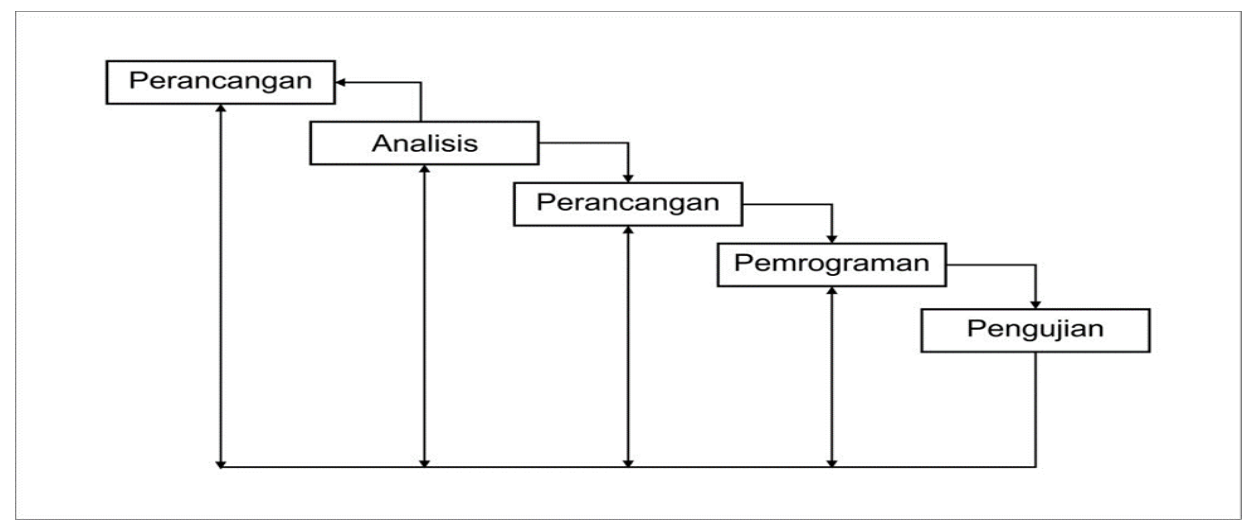

Gambar 1. Alur SLDC Waterfall

\subsection{Tahap Perencanaan Sistem}

Menentukan tujuan dari sistem yang dibuat, yaitu untuk decision support system yang berisi data keluhan penyakit atau nama penyakit pasien. Digunakan empat tenaga 
medis (dokter, perawat, apoteker, dan ahli gizi) dalam mengambil keputusan yang rasional. Setiap masyarakat memiliki email untuk mendaftar dalam aplikasi dimaksudkan sebagai efisiensi.

Herbal Twinning System juga memiliki beberapa fitur diantaranya yaitu fitur diskusi antarpasien, fitur pola hidup sehat, fitur yang memberikan informasi pengobatan herbal, fitur yang memberikan informasi nutrisi yang sesuai dengan penyakit pasien, fitur konsultasi pasien dengan beberapa tenaga medis, dan pasien mendapatkan saran tentang keluhan pasien.

\subsection{Tahap Analisa}

Tahap untuk mencari tahu kebutuhan fungsional dan non fungsional software dan user dengan adanya use case pada gambar 2. Analisis kebutuhan disesuaikan user terhadap interaksi sistem.

Non Fungsional adalah software dan hardware. Adapun software yang dignkan meliputi: Android Studio,Android Emulator,MySql,Firebase,Notepad++ dan Ms.Word. Hardware yang diguakan: Server, FlashDisk, Smartphone (berbasis Android).

Kebutuhan Fungsional Tenaga Medis dan Pasien (User) sebagai pengguna untuk memulainya melakukan login dan user dapat mengakses semua fitur menu terkecuali saat fitur menu To-Consultation Tenaga Medis hanya dapat melihat keluhan dari pasien dan memberikan saran kepada pasien. Sedangkan pasien hanya dapat menuliskan keluhan.

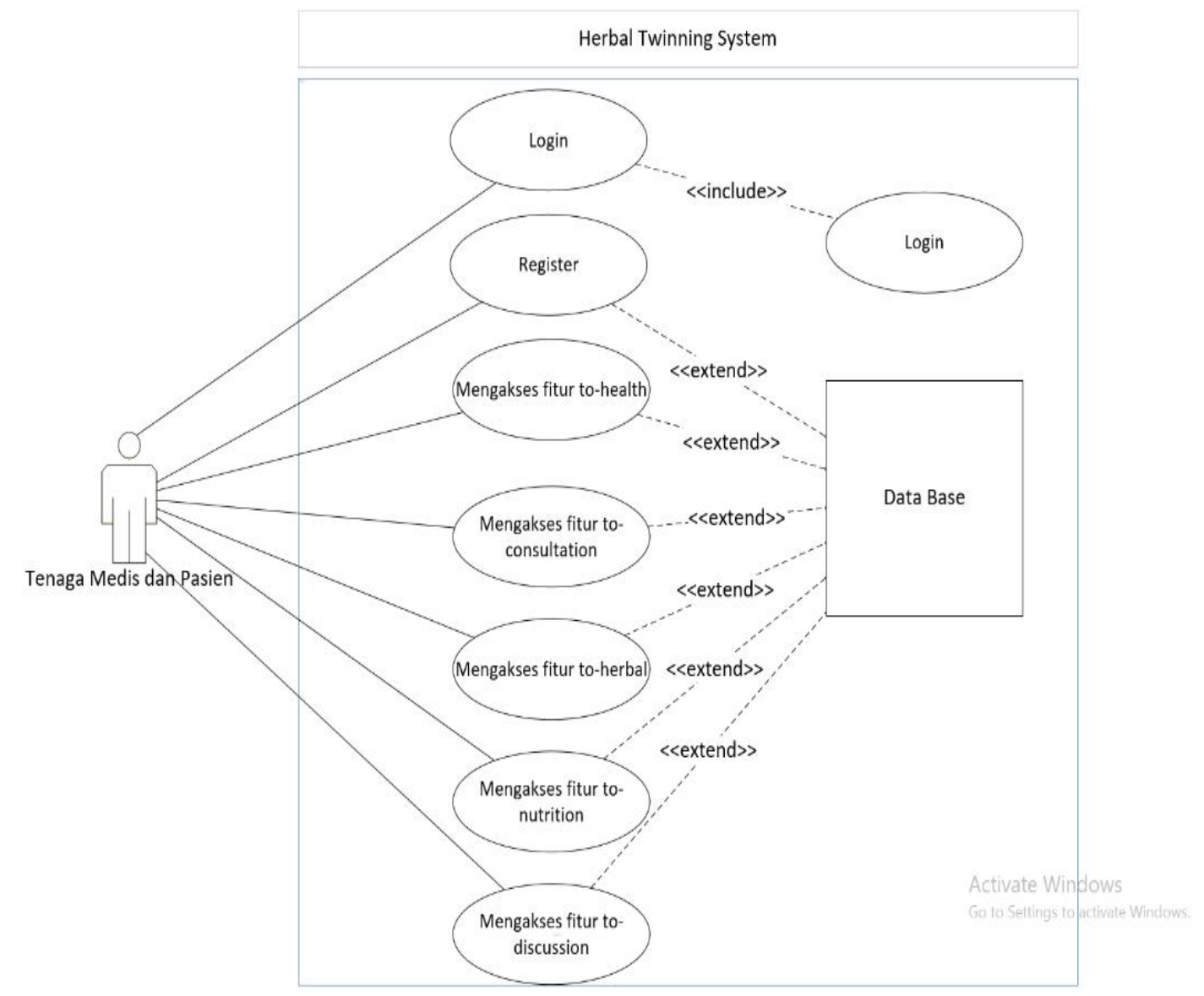

Gambar 2. Use Case Diagram 


\subsection{Tahap Pemeliharaan}

Meliputi penggunaan, audit sistem, penjagaan, perbaikan, dan peningkatan sistem.

\subsection{Tahap Implementasi}

Tahap penerapan dimana desain sistem dibentuk menjadi program yang siap dioperasikan dalam Aplikasi Android.

\subsection{Tahap Perancangan Aplikasi}

Perancangan yang dilakukan untuk memenuhi kebutuhan system yang akan dibuat. Rancangan berupa keluhan pasien dan data pasien yang berbasis android serta dapat diakses oleh pasien yang memiliki penyakit degenartif dengan melallui smartphone.

Perancangan yang dibuat berupa perancangan arsitektur perangkat lunak aplikasi Herbal Twinning System yang dapat dilihat pada Gambar 3.

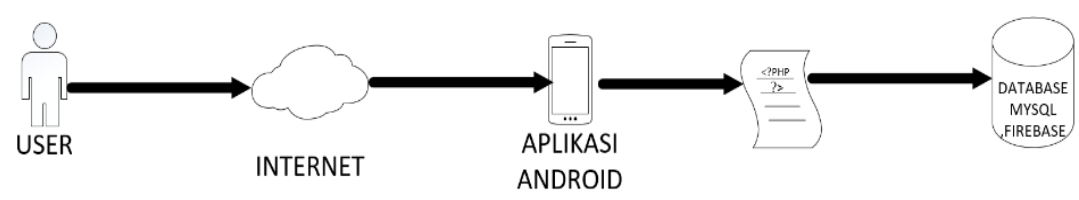

Gambar 3. Deployment Diagram Herbal Twinning System

\subsubsection{HASIL DAN PEMBAHASAN}

\subsection{Hasil}

\section{a. Halaman Utama}

Halaman utama pada Herbal Twininng System berbasis android seperti pada Gambar 4 dirancang sebagai laman login tenaga medis maupun pasien dengan mengisi email dan password. Jika belum mendaftar, maka klik register.

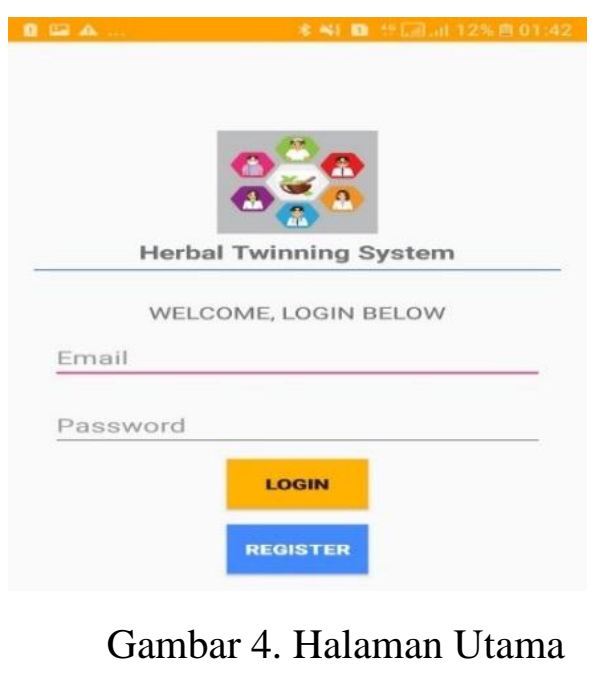

b. Halaman Meuu Awal

Pada menu awal seperti pada Gambar 5 terdapat lima fitur menu yang dapat diakses yaitu To-Health, To-Herbal, To-Consultation, To-Nutrition, dan ToDiscussion. 


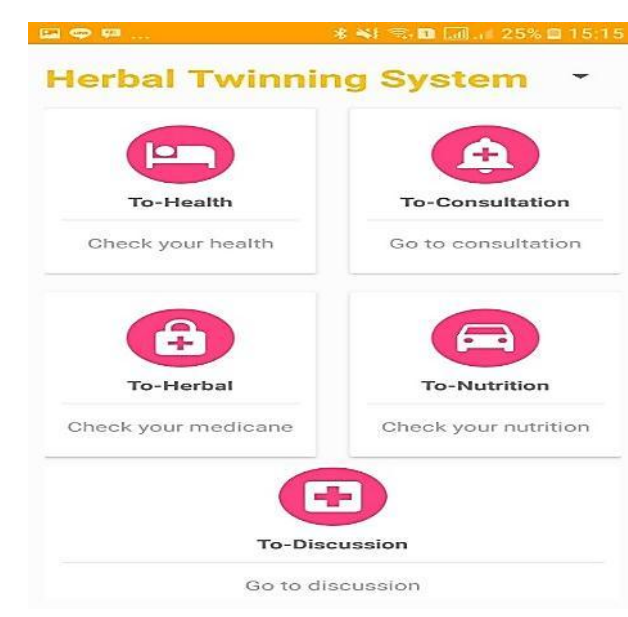

c. Halaman Menu To-Health

Gambar 5. Halaman Meuu Awal

Menu To-Healt seperti pada Gambar 6 berisi sarana informasi pengaturan pola hidup pasien.

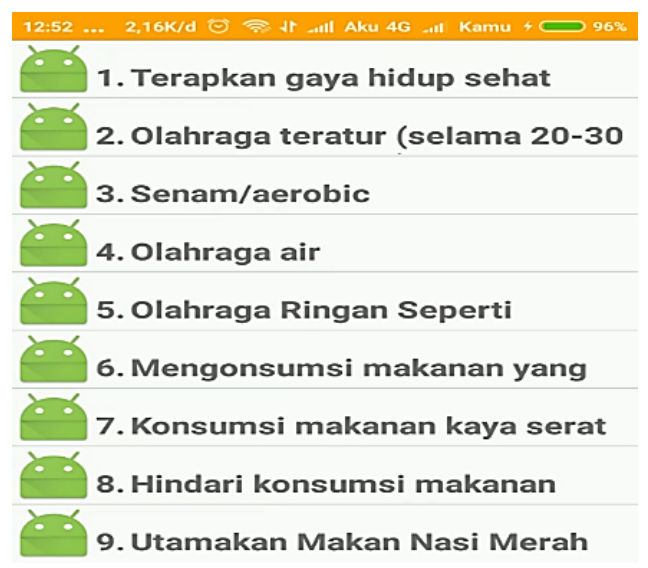

Gambar 6. Halaman Menu To-Health

\section{d. Halaman Menu To-Herbal}

Menu To-Herbal seperti pada Gambar 7 berisi sarana informasi pengolahan obat herbal.

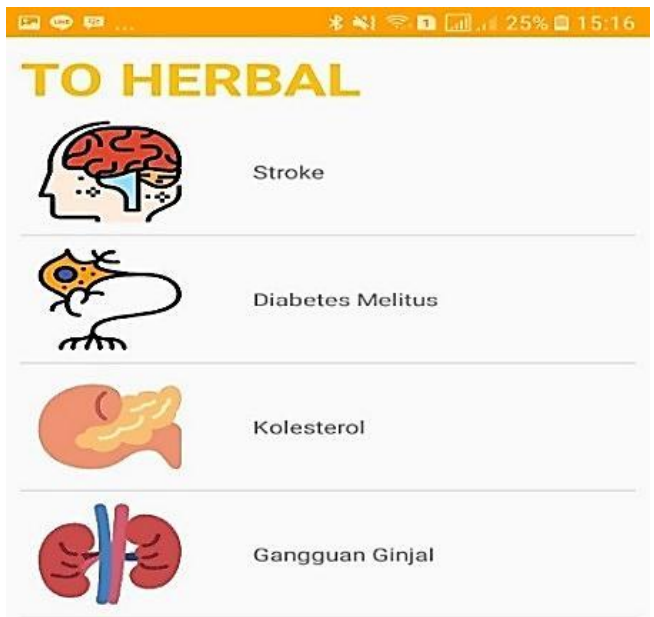

Gambar 7. Halaman Menu To-Herbal 


\section{e. Halaman Menu To-Consultation}

Menu To-Consultation seperti pada Gambar 8 berisi sarana konsultasi pasien dengan tenaga kesehatan.

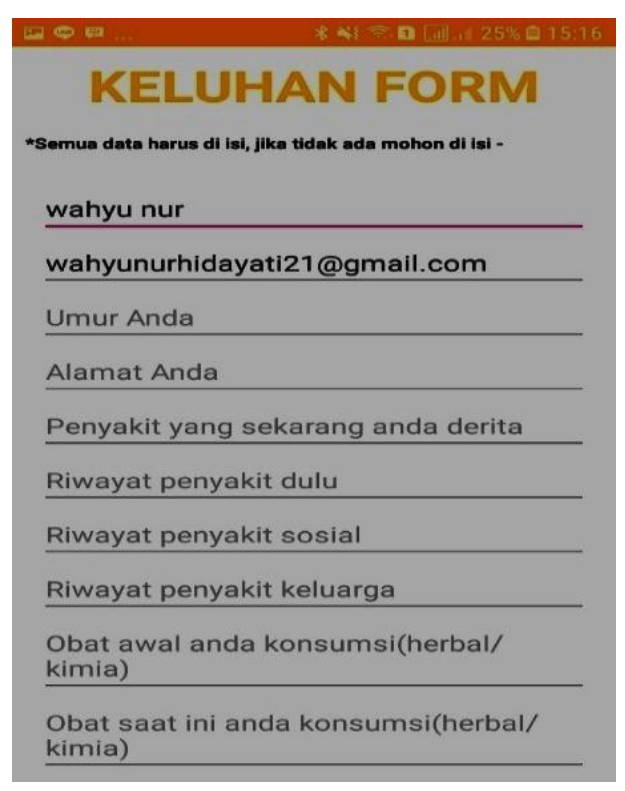

\section{f. Halaman Menu To-Nutrition}

Gambar 8. Halaman Menu To-Consultation

Menu To-Nutrition seperti pada Gambar 9 berisi sarana informasi pengaturan pola nutrisi pasien.

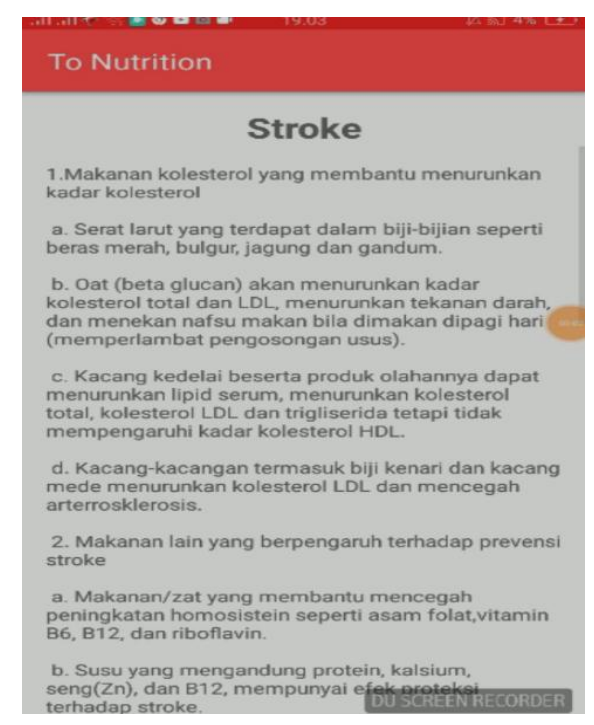

Gambar 9. Halaman Menu To-Nutrition

\section{g. Halaman Menu To-Discussion}

Menu To-Discussion seperti pada Gambar 10 berisi sarana diskusi seperti berkomunikasi dan berbagi pengalaman dengan penderita penyakit sejenis. 


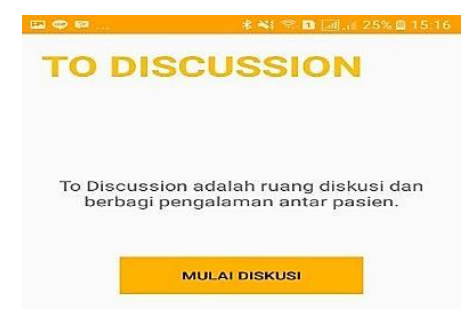

\subsection{Pembahasan}

Gambar 10. Halaman Menu To-Discussion

Penelitian ini dilakukan di Universitas Muhammadiyah Surakarta dan masyarakat di sekitar Pabelan, Kartasura, Sukoharjo sejak April hingga Juni 2018.

Pembuatan aplikasi konseling penyakit degeneratif dalam kaidah IPE (Interprofessional Education) berbasis android telah selesai dilakukan. Sistem yang dibuat memiliki lima fitur yang masing-masing fitur memiliki ciri khas yang berbeda. Pengujian sistem dilakukan oleh masyarakat umum, mahasiswa, dan praktisi kesehatan. Dua orang penguji adalah seorang apoteker yang bekerja di daerah Sragen, tiga orang Tenaga Teknis Kefarmasian (TTK), dan tujuh belas masyarakat umum. Pemilihan penguji dilakukan secara judgement sampling. Pengujian ini dilakukan menggunakan smartphone yang berupa handphone. Penguji dipersilakan untuk membuka aplikasi, menilai tampilan dan fungsionalitasnya. Selanjutnya, penguji diminta mengisi kuisioner yang telah disiapkan. Data hasil pengisian kuisioner dapat dilihat di tabel 1.

Analisis statistika menggunakan skala Likert dengan jumlah pertanyaan sebanyak 10 soal. Skala penilaian terdiri atas sangat setuju, setuju, kurang setuju, dan tidak setuju masing-masing berbobot 4,3,2,1. Skala penilaian lain terdiri atas jawaban ya dan tidak masing-masing berbobot 2 dan 1 . Persentase kepuasan kinerja dihitung dengan rumus:

$$
\text { Presentase } \%=\frac{\text { total point }}{\text { point maksimal }} \times 100 \%
$$

Hasil analisis menunjukkan bahwa sebanyak $91 \%$ responden setuju bahwa aplikasi Herbal Twinning System dapat direalisasikan di masyarakat dan memiliki fitur yang menarik. Besaran tersebut sudah cukup besar karena target awal peneliti hanyalah $80 \%$. Untuk mengoptimalkan kinerja aplikasi, maka peneliti perlu menambah data-data terkait informasi yang lebih akurat.

Tabel 1. Hasil Presentase Kuisioner

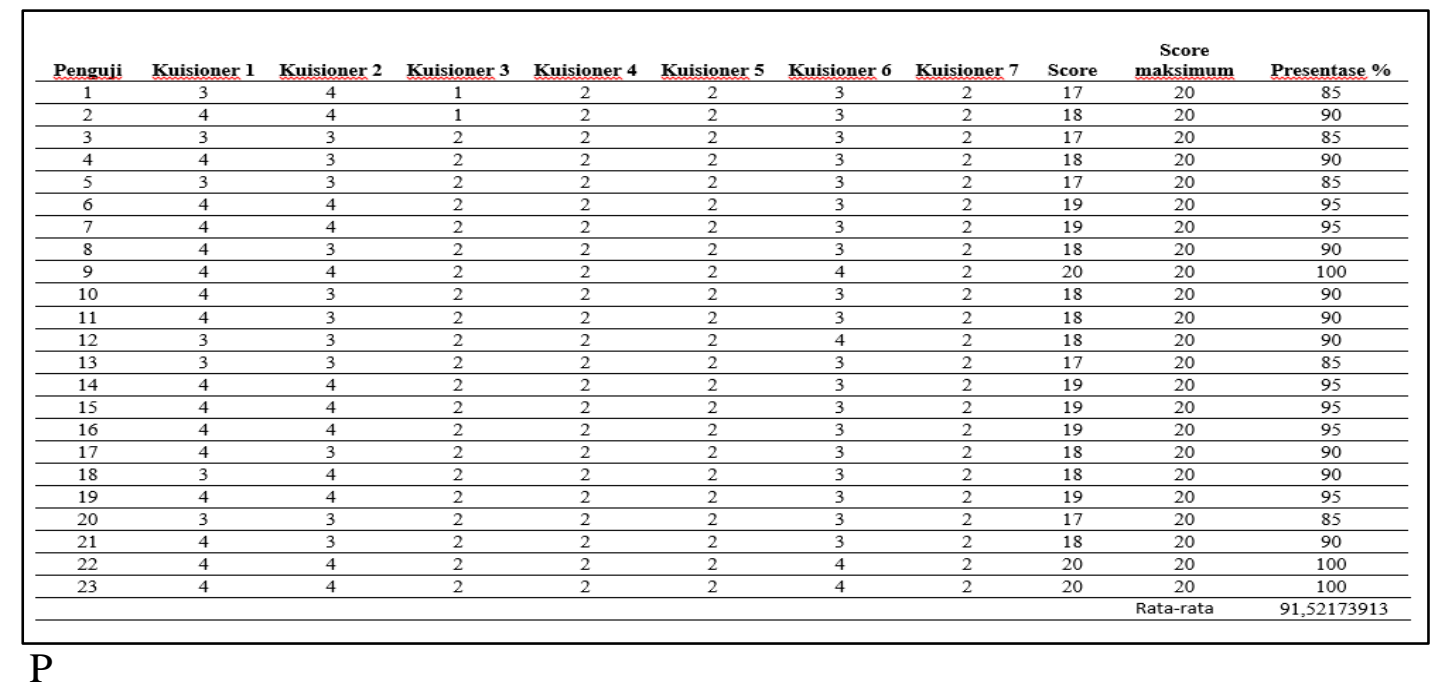


Parameter uji kedua adalah uji black box yang ditunjukkan pada Tabel 2. Metode black box bertujuan untuk menguji kesesuaian hasil antara pembuatan sistem terhadap analisis kebutuhan yang telah dibuat sebelumnya. (Olivya, 2017)

Tabel 2. Uji Black Box

\begin{tabular}{|l|l|l|l|}
\hline Kelas Uji & Skenario Uji & Hasil Yang Diharapkan & Kesimpulan \\
\hline $\begin{array}{l}\text { Uenu Register } \\
\text { User }\end{array}$ & User Melakukan Registrasi & $\begin{array}{l}\text { Username dan Password } \\
\text { tersimpan di Database } \\
\text { Admin dan terdaftar }\end{array}$ & Berhasil \\
\hline $\begin{array}{l}\text { Tampilan Login Pada } \\
\text { Menu Utama }\end{array}$ & $\begin{array}{l}\text { Tekan Tombol Login } \\
\text { setelah memasukan } \\
\text { username dan password }\end{array}$ & Tampil Menu Utama & Berhasil \\
& $\begin{array}{l}\text { Tekan Tombol To Herbal } \\
\text { Tekan Tombol To Health } \\
\text { Tekan Tombol To } \\
\text { Consultation } \\
\text { Tekan Tombol To } \\
\text { Discussion } \\
\text { Tekan Tombol To } \\
\text { Nutrition }\end{array}$ & $\begin{array}{l}\text { Tampil Menu To Herbal } \\
\text { Tampil Menu To Health } \\
\text { Tampil Menu To }\end{array}$ & $\begin{array}{l}\text { Berhasil } \\
\text { Berhasil } \\
\text { Tampil Menu To } \\
\text { Discussion } \\
\text { Tampil Menu To } \\
\text { Discussion }\end{array}$ \\
\hline Menu Logout & Tekan Tombol Logout & Keluar dari aplikasi & Berhasil \\
\hline
\end{tabular}

Pengujian lainnya adalah membandingkan aplikasi pada handphone satu dengan yang lainnya. Aplikasi ini terdiri dari teks dan link video yang berekstensi .apk sehingga untuk memiliki aplikasi aplikasi ini minimal menggunakan android minimum versi 2.3 dan diinstall terlebih dahulu (Murtiwiyati; \& Lauren, 2013). Hasil pengujian dapat dilihat pada Tabel 3.

Tabel 3. Perbandingan Hasil Uji Coba

\begin{tabular}{|c|c|c|c|}
\hline Perangkat Seluler & Spesifikasi & Kelebihan & Kekurangan \\
\hline Samsung J5 (2016) & $\begin{array}{l}\text { Android OS, v5.1 } \\
\text { (Lollipop) - Layar } 5.2 \\
\text { inches, 1280 x } 720 \\
\text { pixels - Memori } \\
\text { internal 16 GB - CPU } \\
\text { Quad-core } 1.2 \mathrm{GHz} \\
\text { Cortex A53 }\end{array}$ & $\begin{array}{l}\text { Teks } \\
\text { terlihat jelas dan } \\
\text { waktu } \\
\text { akses dan perpindahan } \\
\text { antar halaman terasa } \\
\text { cepat dan tanpa jeda }\end{array}$ & Tidak ada kekurangan \\
\hline Vivo Y53 & $\begin{array}{l}\text { Android 6.0 Funtouch } \\
\text { OS } 3.0 \text { (Marshmallow) } \\
\text { - Layar } 5 \text { inches } 960 \text { x } \\
540 \text { pixels - Memori } \\
\text { internal } 16 \mathrm{~GB}-\mathrm{CPU} \\
1,4 \mathrm{GHz}\end{array}$ & Teks terlihat jelas. & $\begin{array}{l}\text { Waktu akses dan } \\
\text { perpindahan halaman } \\
\text { cenderung lama, }\end{array}$ \\
\hline Oppo F5 Youth & $\begin{array}{l}\text { Android } 7.1 \text { (Nougat) - } \\
\text { Layar } 6 \text { inches, } 1080 \text { x } \\
2160 \text { pixels - Memori } \\
\text { internal } 32 \mathrm{~GB}-\mathrm{CPU} \\
\text { Octa-core } 2.5 \mathrm{GHz} \\
\text { Cortex-A53 }\end{array}$ & - & $\begin{array}{l}\text { Tidak bisa terpasang pada } \\
\text { perangkat. }\end{array}$ \\
\hline Oppo Find7 & $\begin{array}{l}\text { Android } 4.3 \text { (Jelly } \\
\text { Bean) - Layar } 5.5 \\
\text { inches, } 1440 \text { x } 2560 \\
\text { pixels - Memori } \\
\text { internal } 32 \text { GB - CPU } \\
\text { Quad-core } 2.5 \mathrm{GHz} \\
\text { Krait } 400\end{array}$ & - & $\begin{array}{l}\text { Tidak bisa terpasang pada } \\
\text { perangkat. }\end{array}$ \\
\hline
\end{tabular}




\section{KESIMPULAN DAN SARAN}

\subsection{KESIMPULAN}

Berdasarkan hasil pengujian, sebanyak $91 \%$ penguji yang meliputi masyarakat dan tenaga kesehatan setuju bahwa aplikasi Herbal Twinning System memiliki fitur menu yang menarik dan bisa direalisasikan di masyarakat umum sehingga bisa disimpulkan bahwa aplikasi Herbal Twinning System sudah bisa memenuhi kebutuhan para pasien penderita penyakit degeneratif dalam monitoring penyakitnya, sarana informasi untuk pengaturan nutrisi maupun pola hidup sehat, dan konsultasi dengan berbagai tenaga kesehatan untuk mencegah kesalahan pada pengobatan (Medication Error).

\subsection{SARAN}

Penelitian dapat dilanjutkan dengan membuat aplikasi sejenis untuk penyakit yang berbeda dan melengkapi fitur yang telah ada. Selain itu, dilakukan kerjasama dengan berbagai organisasi tenaga kesehatan dengan melibatkan pemerintah didalamnya.

\section{PERSANTUNAN}

Peneliti berterimakasih kepada DIKTI atas diterimanya usulan proposal penelitian Program Kreativitas Mahasiswa (PKM) Karsa Cipta, penguji, praktisi kesehatan, dan responden yang telah ikut serta mendukung penelitian ini.

\section{DAFTAR PUSTAKA}

Breu, F., Guggenbichler, S., \& Wollmann, J. (2013). World Health Statistics 2013. Vasa. https://doi.org/978924156458 8

Head, D. O. F. R., Arms, P. R., Watanabe, K., Kawakami, N., \& Tachi, S. (2009). Rancang Bangun Aplikasi Konsultasi Makanan Sehat bagi Penderita Diabetes Berbasis Mobile Menggunakan Teknologi J2ME, 14(3), 3-6.

Hind M., Norman I., Cooper S., Gill E. 2003. Interprofesional Perception of Health Service Student. Journal Interprofesional Care. Serial online.

Kemenkes RI. 2012. Penyakit Tidak Menular. Buletin Jendela ISSN 2088-270X 2012.

Kongres PERSI. (2012). Laporan Peta Nasional Insiden Keselamatan Pasien. Jakarta.

Meinarwati. 2015. Potensi Herbal Indonesia Menjanjikan. Retrieved Desember 12, 2017, from http://www.beritasatu.com/kesehatan/395192-potensi-herbal-indonesiamenjanjikan.html

Mendag. 2013. Obat Herbal Tradisional. Warta Ekspor. Ditjen PEN/MJL/005/9/2014.

Murtiwiyati;, \& Lauren, G. (2013). Rancang Bangun Aplikasi Pembelajaran Budaya Indonesia Untuk Anak Sekolah Dasar berbasis Android. Jurnal Ilmiah KOMPUTASI, 12, 2,3. https://doi.org/1412-9434

NCC MERP. (2016). National Coordinating Council for Medication Error Reporting and Prevention. Retrieved Desember 12, 2017, from http://www.nccmerp.org/aboutmedication-errors

Olivya, M. (2017). Sistem Informasi Pemasaran Hasil Pertanian Berbasis Android. Jurnal Inspiration, 7, 60-69. 